Felicity Meakins* and Rachel Nordlinger

\title{
Possessor dissension: Agreement mismatch in Ngumpin-Yapa possessive constructions
}

DOI 10.1515/lingty-2017-0004

Received November 18, 2015; revised May 3, 2016

Abstract: In this article we describe a possessive construction in the NgumpinYapa languages of Australia which has interesting implications for crosslinguistic models of agreement. In this "possessor dissension" construction, the possessor NP remains a modifier within the larger possessive NP, yet both the possessor and the possessum are cross-referenced with clause-level agreement morphology. Thus, there is a type of morphosyntactic disagreement (or dissension) between the syntactic position of the possessor as an NP-internal argument and its being agreed with at the clausal level as if it were a clausal argument. This phenomenon has had only limited mention in the typological literature, and has not previously been discussed for Australian languages. We discuss the properties of the construction, how it can be distinguished from other related construction types, and its implications for the typology of agreement.

Keywords: agreement, alienable vs. inalienable possession, argument vs. adjunct, Australian, benefactive/malefactive, cross-reference, external possessor, morphology, Ngumpin-Yapa languages, possession, syntax

\section{Introduction}

In this article we discuss a particular possessive construction found in Bilinarra, Gurindji, and other Ngumpin-Yapa languages of northern Australia, which we will refer to as "possessor dissension". ${ }^{1}$ In this possessive

1 The term "possessor dissension" (cf. descent/dissent) is meant as a play on the term "possessor ascension" and reflects the dissonance in agreement insofar as the possessor is syntactically a modifier within the NP but is agreed with by the verb as if it were a clausal argument.

*Corresponding author: Felicity Meakins, School of Languages and Cultures, Level 3, Gordon Greenwood Blg, University of Queensland, Brisbane QLD 4072, Australia, E-mail: f.meakins@uq.edu.au

Rachel Nordlinger, School of Languages and Linguistics, University of Melbourne, Melbourne VIC 3010, Australia, E-mail: racheln@unimelb.edu.au 
construction we find a mismatch in the morphosyntactic encoding of the possessor: although it remains clearly an embedded modifier of the possessive NP, it is cross-referenced ${ }^{2}$ with clause-level agreement morphology as if it were an argument of the clause: ${ }^{3}$

(1) Gurindji

\begin{tabular}{|c|c|c|c|c|}
\hline Ngayiny $_{\mathrm{PSR}}$ & karu $\left._{\mathrm{PSM}}\right]_{\mathrm{PSP}}$ & $n g u=\boldsymbol{y} \boldsymbol{i}_{\mathbf{P S R}}=\boldsymbol{u}_{\mathrm{PSP}}$ & warrngun & karrinya \\
\hline 1MIN.DAT & child & $\mathrm{CAT}=1 \mathrm{MIN} . \mathrm{O}=3 \mathrm{AUG} . \mathrm{S}$ & ache & be.PST \\
\hline
\end{tabular}

This is crucially different to "external possessor" or "possessor raising" constructions (e.g., Payne \& Barshi (eds.) 1999) as in (2), since there is clear evidence that the possessor remains embedded within the possessum NP - i.e., there is no "raising" or valency-changing - despite its being treated as a clausal argument by the clause-level agreement morphology.

\section{(2) Gurindji}

$\begin{array}{lllll}{\left[\text { Ngayu }_{\mathbf{P S R}}\right]} & n g u=\boldsymbol{r n a} \boldsymbol{A}_{\mathbf{P S R}} & {\left[\text { mila }_{\mathbf{P S M}}\right]} & \text { warrngun } & \text { karrinya } \\ 1 \mathrm{MIN} & \text { CAT=1MIN.S } & \text { eye } & \text { ache } & \text { be.PST }\end{array}$

'My eyes were aching.'

The possessor dissension construction also differs from the more familiar alienable possession lacking agreement with the possessor, as shown in (3).

\footnotetext{
2 A reviewer points out that while some researchers see a clear distinction between "agreement" and "cross-reference" we use the terms somewhat interchangeably. In doing so, we follow Corbett (2003: 117) who discusses extensively the difficulties in distinguishing between them and concludes "there is no reason to treat 'cross-referencing' as radically different from agreement" (see also Siewierska 2011). This is particularly evident in the languages we discuss, where argument NPs are freely omitted so that the same clitic bound pronouns are sometimes functioning as "agreement" markers (when the corresponding NP is present in the clause), and at other times functioning as "cross-referencing” pronouns (when the corresponding NP is omitted) (e.g., see Bresnan \& Mchombo 1987). Rather than impose an unnecessary distinction, we just use the two terms interchangeably.

3 Examples (1) to (3) are constructed for the purposes of clearly illustrating the grammatical differences between the construction types. We illustrate more fully with real examples from our corpus in Section 3. We use the following subscript abbreviations for components of possessive constructions where relevant: PSR possessor, PSM possessum, PSP possessive phrase.
} 
(3) Gurindji

$\begin{array}{lllll}{\left[\text { Ngayiny }_{\mathbf{P S R}}\right.} & \left.\text { karu }_{\mathbf{P S M}}\right]_{\mathbf{P S P}} & \mathbf{n g u}=\mathbf{l} \boldsymbol{u}_{\mathbf{P S P}} & \text { warrngun } & \text { karrinya } \\ \text { 1MIN.DAT child } & \text { CAT=3AUG.S } & \text { ache } & \text { be.PST } \\ \text { 'My children were aching.' } & & \end{array}$

Such constructions have received only limited discussion in the typological literature (e.g., Comrie (2003) as "trigger-happy agreement"; Corbett (2006: 61) as "verb agreement with possessives"; Dalrymple \& Nikolaeva (2011) as a type of "topical non-subject agreement"), although they have been reported in a number of unrelated languages including Maithili (Indo-Aryan, India and Nepal; Stump \& Yadav 1988), Santali (Austroasiatic, India; Neukom 2001: 111-112), Itelmen (Chukotko-Kamchatkan, Russia; Bobaljik \& Wurmbrand 2002), and Tundra Nenets (Samoyedic, Russia; Nikolaeva 2014). ${ }^{4}$ They have not, however, been previously discussed in any detail for Australian languages, despite the fact that examples are readily found scattered through the grammatical descriptions of Ngumpin-Yapa and other Australian languages, as we show in the discussion throughout this article.

This construction has interesting typological and theoretical implications, which arise from its involving clause-level (verbal) agreement with an NP that is embedded within a clausal argument, rather than being a clausal argument itself. In other words, there is a type of morphosyntactic disagreement (or dissension) between the syntactic position of the possessor as an NP-internal modifier, and its treatment as an oblique argument at the clausal level. Such facts suggest that we need to either expand our traditional notions of agreement to allow for this type of non-local agreement, whereby a clause-level agreement marker can be controlled by a modifier within an argument/adjunct NP; or alternatively allow flexibility in our syntactic models such that a possessor NP can be at once both a modifier embedded within an argument/adjunct NP and a clausal oblique argument controlling clause-level agreement.

In this article we discuss the structural properties of the possessor dissension construction in Ngumpin-Yapa languages (Section 3), and contrast it with related constructions such as other possessive constructions (Section 4) and the benefactive/malefactive construction (Section 5). In Section 6 we consider the implications of the possessor dissension construction for theoretical and typological analysis, particularly for standard assumptions about agreement. First, however, we provide a brief overview of the Ngumpin-Yapa languages, with

4 Nikolaeva (2014) provides a more complete typological picture of the phenomenon, which she refers to as involving "NP-internal prominent possessors". 
particular attention given to the structure and functional range of pronominal clitics and dative-marked nominals.

\section{An overview of the structure of Ngumpin-Yapa languages}

Ngumpin-Yapa languages are spoken in north-western Australia, extending west to Fitzroy Crossing, where Walmajarri is spoken, and east to Elliott, where Mudburra is spoken. The northernmost Ngumpin-Yapa language is Ngarinyman, spoken at Yarralin, Amanbidji, and Bulla, with the language family extending as far south as Yuendumu, where Warlpiri is spoken. Map 1 gives the location of most of the Ngumpin-Yapa languages.

Ngumpin-Yapa languages are made up of the Ngumpin and Yapa subgroups (McConvell \& Laughren 2004). Ngumpin languages consist of the Western branch which includes Walmajarri (Hudson 1978; Richards 1979), Ngardi (also called Ngardilyi) (Cataldi 2011), Jaru (Tsunoda 1981), and Nyininy, and the

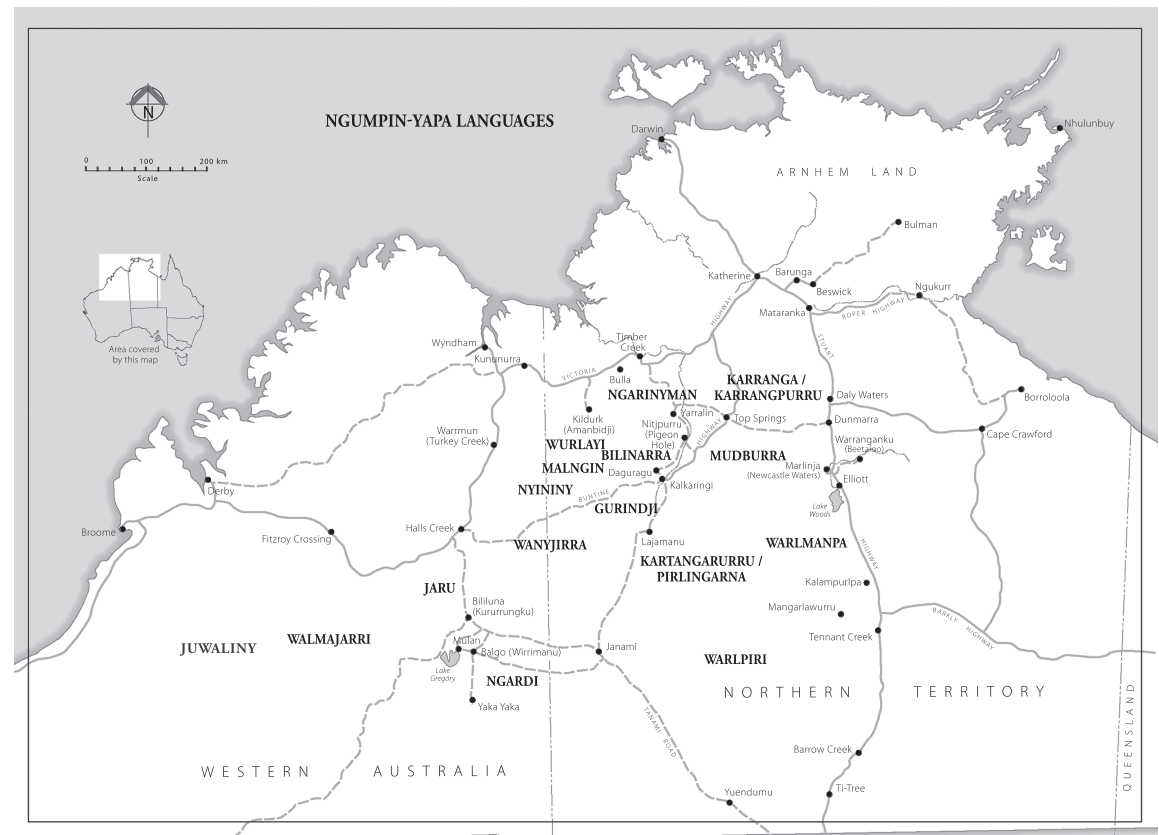

Map 1: Location of Ngumpin-Yapa languages (map by Brenda Thornley, 2016). 
Eastern Ngumpin subgroup which includes Wanyjirra (Senge 2015), Gurindji (Meakins et al. 2013) and Malngin (Ise 1998) (which are dialects), Bilinarra (Meakins \& Nordlinger 2014) and Ngarinyman (which are dialects), Karrangpurru (also called Karranga), and Mudburra. Warlpiri (Hale 1982; Laughren \& Hoogenraad 1996; Nash 1986; Simpson 1991) and Warlmanpa constitute the Yapa languages. The relationship between these languages is shown in Figure 1.

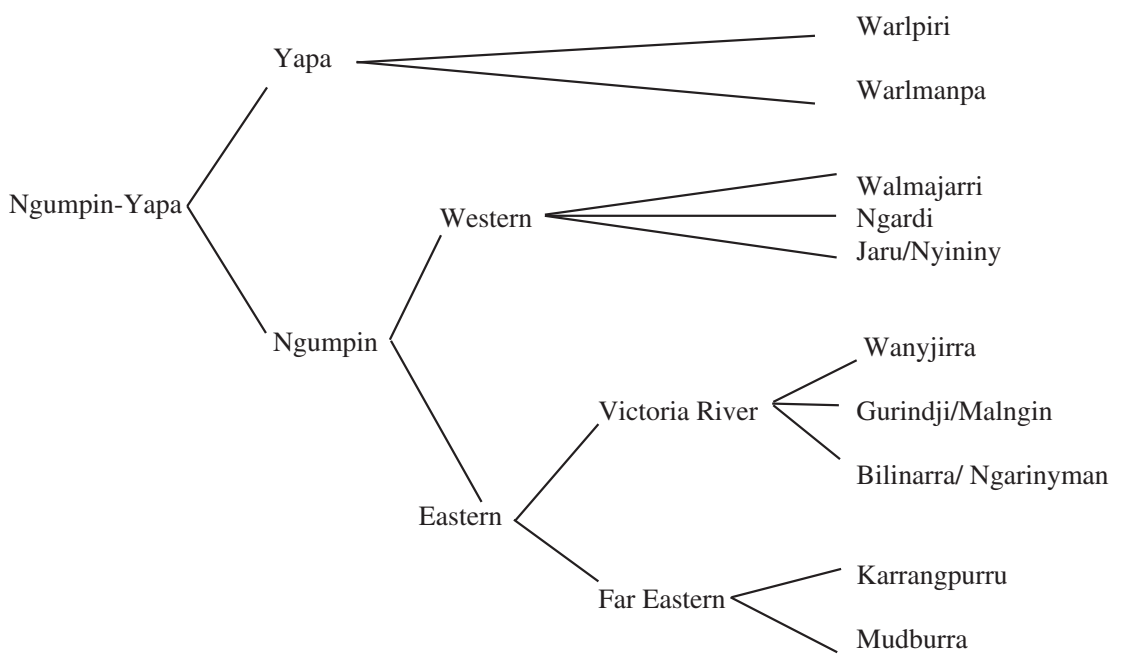

Figure 1: Genealogy of Ngumpin-Yapa (based on McConvell 2009).

All Ngumpin-Yapa languages have fared badly since the 1860s when European settlers first began colonising this area of Australia. Karrangpurru, Bilinarra, and Malngin are no longer spoken. Walmajarri, Mudburra, Ngardi, Ngarinyman, and Gurindji are no longer being learnt by children, with Gurindji, Bilinarra, and Ngarinyman children now acquiring a mixed language, Gurindji Kriol (Meakins 2011). Only Warlpiri remains strong, although Kriol/English influence is evident in the northernmost variety spoken at Lajamanu where a mixed language, Light Warlpiri, has also developed (O’Shannessy 2009).

Ngumpin-Yapa languages belong to the widespread Pama-Nyungan family and are fairly typical Pama-Nyungan languages. They are suffixing, agglutinating languages, with no prefixes or proclitics, and they exhibit a mix of dependent-marking and head-marking. Nominals (nouns, adjectives, demonstratives) which are core arguments are case-marked and are cross-referenced by 
obligatory pronominal clitics, which generally attach to a second-position auxiliary, see (4a). The nominals are marked according to an ergative-absolutive alignment pattern (4a) and pronominal clitics according to a nominativeaccusative system (4b); hence Ngumpin-Yapa languages are often termed splitergative languages. ${ }^{5}$ Other case suffixes found across Ngumpin-Yapa languages are dative, locative, allative, ablative, terminative, source, possessive, and perlative (privative, comitative, and proprietive are generally considered adnominal). Pronominal clitics distinguish person (1st, 2nd, and 3rd), with 1st person non-singular also making an inclusive/exclusive distinction; and three numbers (singular, dual, and plural). ${ }^{6}$ No clitic form exists for 3rd person singular subjects and objects, see ( $4 \mathrm{a}, \mathrm{b})$, and other 3rd person forms do not distinguish gender (4c). Free pronouns are also in evidence and are used for emphasising discourse participants. In Yapa languages such as Warlpiri, these pronouns decline much like other nominals (4a), however different patterns can be found in the Ngumpin languages, e.g., in Gurindji, Ngarinyman, and Bilinarra, they are not marked for core grammatical cases at all.

The verb complex in Ngumpin-Yapa languages consists of an obligatory closed-class verb which inflects for tense/aspect/mood (TAM) and a non-obligatory (largely) uninflected open-class coverb. Some differences in the verb complex can be observed across Ngumpin-Yapa languages. For example, Warlpiri has around 120 inflected verbs whereas Bilinarra and Ngarinyman contain only 23; and the coverb in Walmajarri, Warlpiri, and Warlmanpa is generally prefixed to the inflected verb (4c), whereas it is an independent word in all other Ngumpin-Yapa languages (4b). Finally all Ngumpin-Yapa languages exhibit the properties described for non-configurational languages by Hale (1983): pragmatically determined word order, the possibility for discontinuous noun phrases (4c), and the common omission of NPs coupled with the

\footnotetext{
5 Following Goddard's (1982) distinction between case form and case marking, Ngumpin-Yapa languages can actually be analysed as having a tripartite case system which distinguishes the three core case categories: ergative, nominative, and accusative, which map onto the A, S, and O arguments respectively (e.g., Meakins \& Nordlinger 2014 for Bilinarra). Morphologically, however, there is a two-way marking split between nouns and bound pronouns (hence the term "split-ergative"). An accusative marking pattern in the bound pronoun paradigm is the result of syncretism between the ergative and nominative case forms, and an ergative pattern in the nominal system arises from syncretism between the nominative and accusative case forms. 6 The Victoria River languages make a number distinction between minimal, unit augmented, and augmented, which is unusual for Pama-Nyungan languages and may be due to their close proximity with non-Pama-Nyungan languages such as Jaminjung which mark this distinction (Meakins \& Nordlinger 2014: 216). See also Note b to Table 1.
} 
compulsory presence of bound pronouns (4b). ${ }^{7}$ The examples below demonstrate many of these features.

a. Warlpiri

Ngajulu-rlu ka=rna= $\varnothing^{8} \quad$ nya-nyi kurdu.

1SG-ERG PRS=1SG.S=3SG.O see-NPST child.ACC

'I see the child.' (Simpson 1991: 100)

b. Gurindji

Ngu=rna=yina warr kaya-rni nyila jarrwalut

AUX=1MIN.S=3AUG.O catch.up.with kick-PST that many

ngurra-ngka.

camp-LOC

'I caught up with that group (of people) at home.' (VW: FM11_a165:

$36: 36 \mathrm{~min})^{9}$

c. Walmajarri

Kuyi-ngu ma=Ø=nya pina-karriny- $a$ wanyjirri-rlu.

animal-ERG AUX=3SG.S=3PL.O ear-be-PST kangaroo-ERG

'The kangaroo heard them.' (Hudson 1978: 53)

Of particular relevance for this article is the functional range of object/ oblique clitics and dative case marking. The following discussion will be illustrated with examples from Bilinarra. Firstly, a pronominal clitic paradigm for Bilinarra is given in Table $1 .^{10}$

7 A reviewer points out that some Australian languages have also been claimed not to have noun phrases as a consequence of their non-configurational structure (Blake 1983; Heath 1986). In fact, the large majority of Australian languages have been argued to have evidence for NPs (see Nordlinger 2014 for discussion), and the existence of NPs is very clear in the languages under discussion in this article. We review some of the evidence for this in Section 3 where we present our arguments for treating the possessor as being embedded within the possessive NP in the possessor dissension construction.

8 In some examples we use a zero clitic to demonstrate cross-referencing but we consider the clitic to be null. For more information about the pronominal clitic paradigm, see Table 1 .

9 All unpublished Gurindji and Mudburra examples will be referenced with the following information: speaker (two letter initials), recording ID, start time of the utterance in a recording; for example, "VW: FM10_23_1b: 1:24min". The Gurindji and Mudburra speakers were Violet Wadrill and Shannon Dixon.

10 Where more than one referent is encoded, the person and number information of the subject is split and an epenthetic ngu links the object and number information of the subject: SUBJ.PERS-OBJ/OBL-ngu-SUBJ.NUM. Another rule whereby 1st person minimal clitics are positioned before 2nd and 3rd person pronouns, irrespective of grammatical function, also applies (1MIN > 2, 3) as shown in (5a) (Meakins \& Nordlinger 2014: 243). 
Table 1: Pronominal clitics in Bilinarra. ${ }^{\mathrm{a}, \mathrm{b}, \mathrm{c}}$

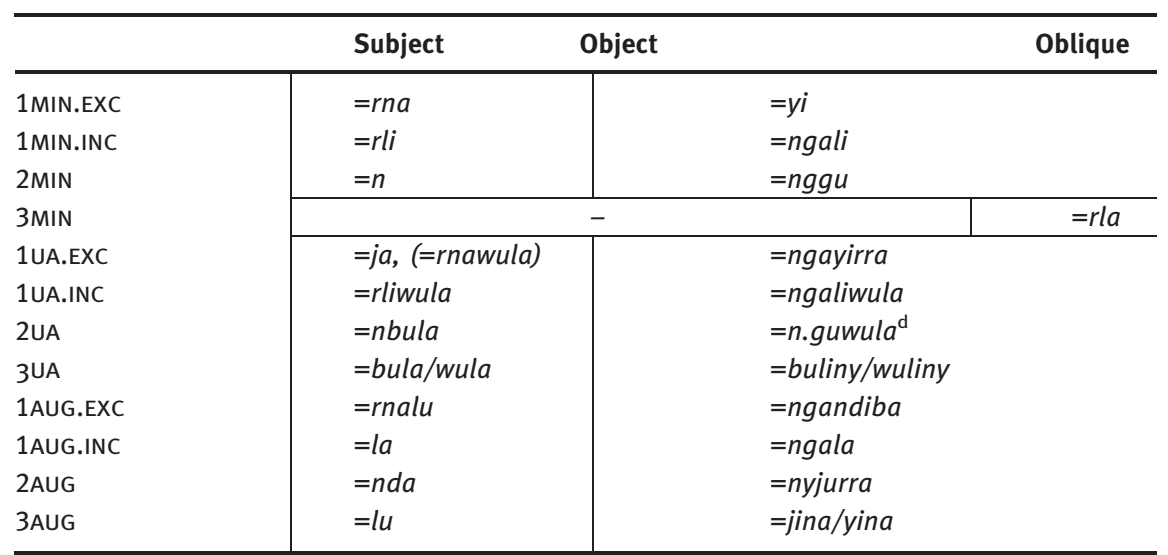

a. These forms are mostly the same in Ngarinyman, Gurindji, and Malngin (with some orthographic differences).

b. This minimal-augmented number system is somewhat unusual for a Pama-Nyungan language, which usually mark singular-dual-plural number categories. Our analysis is motivated by the presence of three inclusive forms: =rli 'you and me', =rliwula 'you, me, and one other', and $=l a$ 'you, me, and two or more others'.

c. In the interests of glossing brevity, we gloss the object and oblique pronominal series as 0 , but readers should remember that it marks obliques and (some) adjuncts, as well as objects. d. The orthography of Bilinarra includes "." between " $n$ " and " $\mathrm{g}$ " to distinguish " $\mathrm{n}$ " + "g" from "ng" (the velar nasal). This is a product of the use of a "bdg" orthography in a language which has no voicing distinction in its stops.

Note that, although 3rd person minimal subjects and objects are not encoded with bound pronouns, as discussed above, a special 3rd person minimal oblique form exists: $=r l a$. The structure of this paradigm is representative of all Ngumpin-Yapa languages except Walmajarri, which distinguishes separate sets of object and oblique pronouns across all numbers and persons. Object/ oblique clitics cross-reference the core object arguments as shown in (5a). ${ }^{11}$ They also cross-reference indirect objects (5b) and oblique arguments which are animate, such as goals (5c) as well as some animate adjuncts such as benefactives $(5 \mathrm{~d})$.

11 Although this cross-referencing is typically described as being obligatory, work by Meakins (2015) shows that its presence varies according to the animacy and grammatical role of the referent. 
(5) Bilinarra

a. Ngamayi-lu ngaji-lu $_{\boldsymbol{A}}=m a=\boldsymbol{y i}_{\boldsymbol{O}}=$ wula $_{\boldsymbol{A}} \quad$ ga-nggu. mother-ERG father-ERG=TOP=1MIN.O=3UA.S take-POT 'Mother and father might take me.' (Meakins \& Nordlinger 2014: 256)

b. Nunyguwarra=wuliny Io $_{\text {garrinya }}$. hungry=3UA.O be.PST 'He was hungry for the two of them.' (Meakins \& Nordlinger 2014: 256)

c. Barunga-gari=rna $\boldsymbol{S}_{\mathbf{S}}$ wuliny $_{\mathbf{G O A L}}=n g a \quad y a-n \cdot g u-r n i=m a$. hot.weather-OTHER=1MIN.S=3UA.O=DUB go-POT-HITH=TOP 'I might return to the two of them next hot weather time.' (Meakins \& Nordlinger 2014: 241)

d. Wanyja-rru warrgab wajarra, gardiba-wu=rlaangulu $\boldsymbol{B E N}_{\mathbf{B}}$ leave-POT dance corroborree white.fellas-DAT=1AUG.INC $>3$ AUG.O jala $=m a$. now $=$ TOP 'We'll dance a corroboree for the whitefellas today.' (Meakins \& Nordlinger 2014: 131)

The dative case marker, which is expressed by the allomorphs -wu (after a vowel-final stem) and - $k u$ (after a consonant-final stem), is used to mark benefactives (5d), indirect objects (6a), animate goals (6b), malefactives (6c), purpose (6d), and alienable possessors (6e). These dative-marked nominals are cross-referenced with a pronominal clitic from the object/oblique series (or =rla '3.oBL'), although generally not if they are inanimate (see Meakins (2015) for a discussion of bound pronoun variability and animacy), as demonstrated by $(6 \mathrm{~d})$, or if they are possessors in an alienable possession construction (as in (6e)).

(6) Bilinarra

a. Jarragab-ba=rna=yina ma-rni $\mathbf{y a l u}-\boldsymbol{w u}=r n i=w a r l a$ talk-EP=1MIN.S=3AUG.O talk-PST that-DAT=ONLY=FOC ngama-rlang-gu.

mother-DYAD-DAT

'So I talked to just those mother and daughters instead.' (Meakins \& Nordlinger 2014: 131)

b. Ngayi=ma=rna=rla=nga ya-n.gu janggarni-wu gardiba-wu. $1 \mathrm{MIN}=\mathrm{TOP}=1 \mathrm{MIN} . \mathrm{S}=3 . \mathrm{OBL}=\mathrm{DUB}$ go-POT big-DAT whitefella-DAT 'I might have to go back to my boss.' (Meakins \& Nordlinger 2014: 131) 
c. Nyamba-wu=yi=nda ngayiny ba-rra warlagu? what-DAT=1MIN.O=2AUG.S 1MIN.DAT hit-PST dog

'Why did you mob kill the dog on me?' (Meakins \& Nordlinger 2014: 132)

d. Ya-ni=lu, garlarra mirlarrang-gu.

go-PST=3AUG.S west spear-DAT

'They went west to (make) spears.' (Meakins \& Nordlinger 2014: 133)

e. Baya-rni=wuliny [ngayiny warlagu jiya]

bite-PST=3UA.O 1MIN.DAT dog kangaroo

'He killed my dog and kangaroo.' (Meakins \& Nordlinger 2014: 203)

The bound pronouns and the dative case suffix form the building blocks of possessive constructions in Ngumpin-Yapa languages, including the possessor dissension construction that is the focus of this article. However, inalienable, alienable, and possessor dissension constructions all combine these pronominal clitics and dative markers in different ways, as discussed in Sections 3 and 4.

\section{Possessor dissension in Ngumpin-Yapa languages}

As shown in (1), in the possessor dissension construction a modifying possessor NP is cross-referenced with a clause-level bound pronoun clitic, as if it were an argument of the clause. When present in the clause (it is not obligatory), the possessor NP is marked with the dative case, which shows it to be a modifier of the NP headed by the possessum (which is obligatory), and is cross-referenced with an object/oblique pronominal clitic. Consider the following examples from a range of Ngumpin-Yapa languages.

(7) a. Gurindji

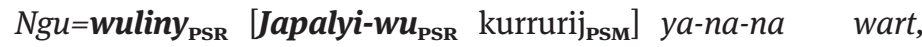

CAT=3UA.O SUBSECT-DAT car go-IMPF-PRS return

jalang $=m a$.

today $=$ TOP

'The car of Jimmy [and Biddy]'s came back today.' (VW: FM09_14_1a:

11:03min)

b. Bilinarra

Nyila $=r n i=$ warla ngayiny $\mathbf{P}_{\mathbf{P S R}}=m a=\boldsymbol{y i}_{\mathbf{P S R}} \quad$ binymala $_{\mathbf{P S M}}$

that $=$ ONLY=FOC 1MIN.DAT=TOP=1MIN.O knife

'That knife is really mine.' (Meakins \& Nordlinger 2014: 209) 
c. Malngin

$\left[\right.$ Ngayiny $_{\mathbf{P S R}}$ warlaku $\left._{\mathrm{PSM}}\right]$ ngu=yi $\mathbf{P}_{\mathrm{PSR}}$ yura paraj pu-nga-na

1MIN.DAT dog CAT=1MIN.O good find pierce-IMPF-PRS

jarrampayi.

large.goanna

'The dog of mine, it is good at finding goannas.' (Ise 1998)

d. Warlpiri

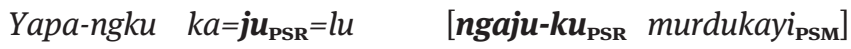

people-ERG PRS=1SG.O=3PL.S 1SG-DAT car

wirrja-pi-nyi.

covet-NPST

'People covet my car.' (Simpson 1991: 11)

e. Jaru

Ngadu nga=rna=nggula $\boldsymbol{A}_{\mathbf{P S R}}$ nyinang-an nngurra $_{\mathbf{P S M}}-n g g a$

1SG CAT=1SG.S=2SG.LOC sit-PRS camp-LOC

nyunungu-la $\left.a_{\mathrm{PSR}}\right]$. $^{12}$

2SG.DAT-LOC

'I sit in your camp.' (Tsunoda 1981: 140)

It is not obligatory that the possessor be expressed with an overt NP (unlike other alienable possession constructions - see Section 4.2 for discussion), and often the pronominal clitic is the sole element encoding the possessor:

(8) a. Wanyjirra

Ngalanga $_{\mathbf{P S M}}$ nyangga $=\mathbf{y} \boldsymbol{i}_{\mathbf{P S R}}$ ya-ngu too gan.guliyin warag-nginyi. daughter AUX=1SG.OBL go-POT too from.up work-ABL

'My daughter comes from up (at the house) after work too.' (Tsunoda 2002: 140)

b. Mudburra

Karndi-li $p a=\boldsymbol{y i}_{\mathbf{P S R}} \quad$ langa-na tyre PSM $_{\mathbf{P M}}$.

stick-ERG AUX=1SG.O poke-PERF tyre

'A stick busted my tyre.' (SD: FM15_a290)

c. Walmajarri

Ngamaji-jarra $^{\mathrm{PSM}}$ pa= pila $_{\mathrm{PSM}}=$ pilangu $_{\mathrm{PSR}}$ ya-ni marri.

mother-DU AUX=3DU.S=3DU.OBL go-PST long.way

'The two mothers of those two (children) went a long way.' (Hudson 1978: 58)

12 In this example, there are three locative forms: two are allomorphs of the locative case marker (-ngga and -la) and the third form is analysed by Tsunoda as a bound pronoun =nggula. 
Since 3rd person singular objects are not cross-referenced in Ngumpin-Yapa languages, often the possessor NP in a possessor dissension construction is cross-referenced while the whole possessive NP in which it is embedded is not. This is what we see in most of the examples above. However, as (9) demonstrates, in the appropriate grammatical conditions, both the possessor NP and the whole possessive NP will be cross-referenced. In this example the whole possessive NP is cross-referenced with the subject pronominal clitic $=l u$ '3AUG.S' while the embedded possessor within the subject is also cross-referenced, with the 1MIN object/oblique clitic. Thus there are two different clitic agreement markers both relating to (parts of) the subject NP ngayiny-ju karu-ngku. Further examples of this “double-marking” are discussed in Section 4.2 below.

\section{(9) Gurindji}

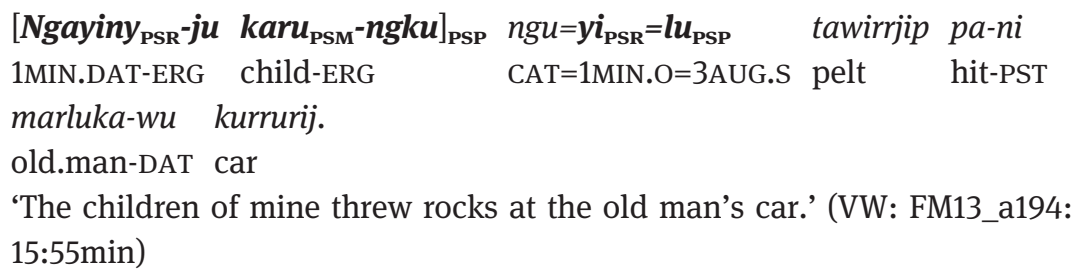

One way to account for the fact that the possessor is cross-referenced as a clausal argument in these examples, independently of the possessive NP itself, would be to argue that the possessor is not, in fact, syntactically embedded in the possessive NP in this construction, but has been "raised" out of the NP to be a clause-level argument (e.g., Payne \& Barshi (eds.) 1999). Such "possessor raising” is common across the world's languages and is well known in the literature. However, there are good reasons against this analysis for the possessor dissension construction that we discuss here. Firstly, as we show in Section 4.1 below, the NgumpinYapa languages have a true "possessor raising" construction that is used to express inalienable (part-whole) possession, and can be shown to be morphosyntactically distinct from the possessor dissension construction in crucial ways. Secondly, there is clear morphosyntactic evidence that the possessor (when present) remains part of the larger possessive NP in these possessor dissension constructions, despite being cross-referenced at the level of the clause.

The evidence for this comes from two sources: (i) both nominals can occur together before the second-position clitic complex suggesting that they are a single constituent; ${ }^{13}$ and more importantly, (ii) the possessor NP must show case agreement

13 As Meakins \& Nordlinger (2014: 256-262) discuss for Bilinarra, second position is the preferred position for bound pronominal clitics, although it is not a strict grammatical position for the 
with the possessum like any other nominal modifier. Both of these structural properties are exhibited in (10a), other examples of case agreement are given in (10b, c).

(10) a. Gurindji

$\left[\text { Ngayiny }_{\mathrm{PSR}} \text {-ju } \text { karu }_{\mathrm{PSM}}-\boldsymbol{n g} \boldsymbol{k u}\right]_{\mathrm{PSP}} n g u=y \boldsymbol{i}_{\mathrm{PSR}}=\boldsymbol{l u}_{\mathrm{PSP}}=r l a_{\mathrm{BEN}}$

1MIN.DAT-ERG child-ERG AUX=1MIN.O=3AUG.S=3.OBL

ka-nya ngarin marluka-wu $\mathbf{B E N}_{\text {. }}$

take-PST meat old.man-DAT

'The children of mine took meat for the old man.' (VW: FM13_a194: 19:48min)

b. Gurindji

$N g u=r n a=$ yina $_{\mathbf{P S R}}=n k u=r l a_{\mathbf{P S P}}$ ngayu- warij $^{14}$ lurlu karrinya na

$\mathrm{CAT}=1 \mathrm{MIN} . \mathrm{S}=3 \mathrm{AUG} . \mathrm{O}=\mathrm{EP}=3$.OBL $1 \mathrm{MIN}-\mathrm{ALONE}$ sit be.PST FOC

[nyarruluny $_{\mathrm{PSR}}-\mathrm{ja}$ ngurra-ngka $]_{\mathrm{PSP}}$.

3AUG.DAT-LOC camp-LOC

'I'm sitting down on my own at that camp of theirs.' (VW: FM13_a196:

$0: 14 \mathrm{~min})$

c. Jaru

Nyila $n g a=\mathbf{y} \boldsymbol{i}_{\mathbf{P S R}}=\boldsymbol{r l a} \boldsymbol{a}_{\mathbf{P S P}} \quad[\text { gunyarr-gu }]_{\mathbf{P S P}}$ guyu $\left[\right.$ nganingu $\left._{\mathbf{P S R}_{\mathbf{R}}-w u}\right]$.

that CAT=1SG.O=3SG.OBL dog-DAT meat 1SG.DAT-DAT

'That meat is for my dog.' (Tsunoda 1981: 139)

\section{Comparison with other possessive constructions}

The possessor dissension construction in the Ngumpin-Yapa languages exists alongside two other more familiar possessive constructions, which have received considerably more attention in the Australianist literature (e.g., Dixon 1980, 2002): inalienable and alienable possession constructions. While possessor dissension constructions share some properties with these other possessive construction types, as we show in this section, they can be distinguished categorically from other possessive constructions on the basis of a number of morphosyntactic characteristics.

Ngumpin languages as it is in Warlpiri, for example (Simpson 1991). However, even in the Ngumpin languages it is a strong tendency, and in the cases where the bound pronominal clitics appear in third position (as would be the case were the two nominals not part of the same NP in (10a), for example), the elements preceding them are subject to strong discourse conditions.

14 Note that the ngayu-warij 'by myself' is crucial to the analysis of this sentence as being a possessor dissension construction. Without it, this sentence could conceivably mean 'I sat down with them at their camp', which is a standard alienable construction. 


\subsection{Distinguishing inalienable possession}

Inalienable possession constructions mark inalienable relationships or "an indissoluble connection between two entities" (Chappell \& McGregor 1995: 4). Crosslinguistically part-whole relationships usually involve inherent or unchangeable relationships between the possessor and possessed, e.g., the relationship between animate entities and their body parts, kin, position in space, or closely associated objects such as tools. In Ngumpin-Yapa languages, inalienable possession marks relations involving body parts (11a) and images, reflections, or shadows (11b). In some languages such as Warlpiri and Wanyjirra, inalienable possession is also used to mark the nominal "name" (11c). This use is not in evidence in Gurindji, Bilinarra, or Ngarinyman and not reported for the other Ngumpin-Yapa languages.

(11) a. Bilinarra

Jamana $=n a=y i$ gadaj ba-ni, gungulu-g.

foot=FOC=1MIN.O cut hit-PRS bleed-FACT

'Something cut my foot and made it bleed.' (Meakins \& Nordlinger 2014: 205)

b. Wanyjirra

Ngu=rna=yanu ngandawi ma-n.gu.

AUX=1SG.S=3PL.O photo do-POT

'I will take a photo of them.' (Tsunoda 2002: 170)

c. Wanyjirra

Ngu=rnalu=yanu garra-nana guliyan wajbali yiri.

AUX=1PL.EXC.S=3PL.O remember-PRS aggressive whitefella name

'We remember the aggressive whitefellas' names.' (Tsunoda 2001: 180)

Inalienable possession in Ngumpin-Yapa languages is encoded with an "external possession" (or "possessor-raising") construction (Payne \& Barshi (eds.) 1999) in which the possessor is the verbal argument, rather than a dependent of the NP headed by the possessum. This is shown by (i) a pronominal clitic cross-referencing the possessor as an argument of the verb - as a subject (12a), object (12b, c), or indirect object; and (ii) identical relational case marking (in the sense of Dench \& Evans (1988)) on any nominals encoding the possessor ${ }_{\mathrm{PSR}}$ and possessum $_{\mathrm{PSM}}$, with neither marked as a dependent, as in (11c) and (12d). Possessors may also be expressed using a free pronoun, as shown in (12a-b), in which case they appear in the appropriate relational case for the argument function they perform (e.g., subject, object, indirect object, etc.). Such overt nominals are grammatically optional however, and often the possessor is only expressed by a bound pronoun, see (11a, b) above and (12c) below. 
(12) a. Bilinarra

$N g a r r a b-b a=r n a_{\mathrm{PSR}} \quad m a-n i \quad$ buya $_{\mathrm{PSM}}=\boldsymbol{m a} \quad \boldsymbol{n g a y i}_{\mathrm{PSR}}=\boldsymbol{m a}$.

hot-EP=1MIN.S do-PST body=TOP $1 \mathrm{MIN}=\mathrm{TOP}$

'My body is heating up.' (Meakins \& Nordlinger 2014: 206)

b. Gurindji

Karu-ngku ngu=yi $\boldsymbol{i}_{\mathbf{P S R}}$ ma-ni patpat wartan $_{\mathrm{PSM}}$ ngayu $_{\mathrm{PSR}}$.

child-ERG CAT=1MIN.O do-PST feel.REDUP hand 1MIN

'The child feels my hand.' (VW: FM14_a228)

c. Warlpiri

Kinwinyi-rli $\quad k a=j u_{\mathbf{P S R}} \quad \boldsymbol{y a l y u _ { \mathbf { P S M } }}$ kunykuny-nga-rni.

mosquito-ERG PRS=1SG.O blood suck.REDUP-eat-NPST

'The mosquito sucks my blood.' (Simpson 1991: 31)

d. Bilinarra

Girrawa $_{\mathbf{P S R}}$ nyawa $=m a$ yuwa-ni=lu $=\emptyset_{\mathbf{P S R}} \quad$ plate- $d a$

goanna this=TOP put-PST=3AUG.S=3MIN.O plate-LOC

jawud $_{\mathrm{PSM}}$.

tail

'Here they put the goanna's tail on the plate.' (Meakins \& Nordlinger 2014: 204)

Crucially, in inalienable possessive constructions there is no bound pronoun cross-referencing the possessum, only the possessor. For example in (13), only 'their' is registered with a bound pronoun, not 'two knees' (which would require a unit augmented (UA) pronominal clitic).

(13) Gurindji

Jiya-rna-na ngu=yina $\boldsymbol{P S R}_{\mathbf{P R}}$ [kuya-ny-kujarra

burn-IMPF-PRS CAT=3AUG.O thus-NMLZ-DU

tingarri-kujarra-purrupurru $]_{\mathbf{P S M}}$.

knee-DU-AND

'It smokes their pairs of body parts (they need for crawling) including their two knees.' (VW: FM08_a085: 7:05min)

The cross-referencing of the possessor with a pronominal clitic is a feature shared by both inalienable possession and possessor dissension constructions. However, the constructions can nonetheless be clearly distinguished, as the possessor is cross-referenced differently in each case. In inalienable possession, different forms of the pronominal clitic (subject, object/oblique) can be found cross-referencing the possessor, depending upon the grammatical function of the possessor in the clause (see the examples in (11b, c) and (12a-c) above). In 
possessor dissension constructions, however, the possessor is always an oblique and cross-referenced as such, irrespective of the grammatical function of the larger possessive NP. This difference follows from the fact that the bound pronoun reflects the grammatical relation of the possessor: in an inalienable construction, the possessor bears an argument relation to the verb (which may be subject, object, etc.); whereas in a possessor dissension construction the possessor is always a dependent of the possessive NP (and therefore always an oblique). This is illustrated in the pair of Bilinarra examples in (14). In the inalienable possession construction in (14a), the possessor is cross-referenced with the subject bound pronoun =rna reflecting the fact that it is functioning as the subject argument of the clause. In the possessor dissension construction in (14b), on the other hand, the possessor is cross-referenced with the object/ oblique bound pronoun despite the possessive phrase as a whole functioning as the subject of the clause.

(14) Bilinarra

a. Ngarrab-ba=rna $\boldsymbol{P S R}_{\mathrm{PS}}$ ma-ni buya $_{\mathrm{PSM}}=\boldsymbol{m a} \boldsymbol{n g a y i}_{\mathrm{PSR}}=\boldsymbol{m a}$.

hot-EP=1MIN.S do-PST body=TOP $1 \mathrm{MIN}=\mathrm{TOP}$

'My body is heating up.' (Meakins \& Nordlinger 2014: 206)

b. Ngayiny $_{\mathbf{P S R}^{-}}-b a=y \boldsymbol{i}_{\mathbf{P S R}}$ nyila=ma warlagu=ma.

1MIN.DAT-EP=1MIN.O that=TOP dog=TOP

'My (dog) is that dog.' (Meakins \& Nordlinger 2014: 208)

That the possessor in possessor dissension constructions has the role of an oblique is shown most clearly in Walmajarri, which maintains distinct series of object and oblique clitic pronouns. The Walmajarri possessor dissension example in (15) shows that the possessor is cross-referenced with an oblique clitic even when the possessive NP occupies the object position in the clause:

(15) Walmajarri

$\begin{array}{llll}\text { Manga } & p a=j i & k a-n y a & \text { ngaju-wu. } \\ \text { girl } & \text { AUX=1SG.OBL take-PST } & \text { 1SG-DAT } \\ \text { 'He carried my girl.' (Hudson 1978: 26) }\end{array}$

Examples (16a-d) from a range of other Ngumpin-Yapa languages likewise illustrate that the possessor in a possessor dissension construction is always cross-referenced with an object/oblique bound pronoun clitic irrespective of the grammatical function of the possessive phrase to which it belongs. 
(16) a. Gurindji

Ngu $=$ wuliny $_{\mathbf{P S R}}\left[\text { Japalyi-wu } \boldsymbol{P A R}_{\mathbf{P R}} \text { kurrurij }\right]_{\mathrm{PSP}}$ ya-na-na wart, CAT=3UA.O SUBSECT-DAT car go-IMPF-PRS return jalang $=m a$. today $=$ TOP

'Jimmy [and Biddy]'s car came back today.' (VW: FM09_14_1a: 11:03min)

b. Walmajarri

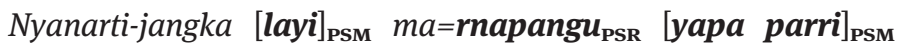
that-ABL one AUX=1PL.EXC.OBL child boy mimi-jarriny-a jina. sore-INCHO-PST foot

'Then one of our boys got a sore foot.' (Hudson 1978: 87)

c. Warlpiri

Ngarrka-ngku $k a=$ jana $_{\mathbf{P S R}}=r l a \quad$ karnta-patu-k $\boldsymbol{u}_{\mathbf{P S R}} k u r d u-k u$ man-ERG PRS=3PL.O=3.OBL woman-PL-DAT child-DAT miyi $_{\mathbf{P S M}}$ marlaja-yi-nyi. food cause-give-NPST

'The man gives the women's food to the child.' (alternatively, 'The man gives the food to the child because of the women.') (Simpson 1991: 387$)^{15}$

d. Jaru

Yalu-nggu mawun-du nga=nggu $\mathbf{P S R}_{\mathbf{P}}=$ janu $_{\mathbf{P S P}}$ ga-nya

that-ERG man-ERG CAT=2SG.O=3PL.O take-PST

[murrgun yamba-aba $a_{\mathbf{P S M}}$ nyunung $\left.\boldsymbol{a}_{\mathbf{P S R}}\right]_{\mathbf{P S P}}$.

three children.REDUP 2SG.DAT

'That man took away your three children.' (Tsunoda 1981: 139)

The distinction between possessor dissension constructions and other possessive constructions is seen most clearly in clauses where the possessive phrase is non-singular, where an overt pronominal clitic agrees with the whole possessive NP and an object/oblique clitic simultaneously agrees with the embedded possessor. Where the whole possessive phrase $\mathrm{PSP}_{\mathrm{PS}}$ is a subject, as in (17), it is encoded using a pronominal clitic which reflects its grammatical role (here $=l u$ ) while the possessor $_{\mathrm{PSR}}$ is encoded using an object/oblique pronominal clitic (here $=y i$ ). In this respect the possessor

15 We assume that this sentence could also be interpreted as a benefactive, i.e., 'The man gives the food to the women for the child', but since this is not mentioned by Simpson, we cannot be certain. 
dissension construction is distinguished from both inalienable and alienable possession constructions (see Section 4.2), which each cross-reference only one relation (the possessor and the possessive phrase, respectively), whereas in the possessor dissension construction both participants in the possessive construction are cross-referenced. This results in a type of "double-marking" whereby there are two different clause-level agreement markers corresponding to the same argument: one cross-referencing the embedded possessor and the other cross-referencing the whole argument NP.

(17) Bilinarra

a. Nyila $=m a=y i_{\mathrm{PSR}}=\boldsymbol{l u}_{\mathrm{PSP}} \quad\left[\text { ngayiny }_{\mathrm{PSR}} \text { jimarri } \boldsymbol{P}_{\mathrm{PSM}}\right]_{\mathrm{PSP}}$.

that $=$ TOP=1MIN.O=3AUG.S 1MIN.DAT friend

'They are my mates.' (Meakins \& Nordlinger 2014: 211)

b. Gurindji

$\left[\text { Ngayiny }_{\mathrm{PSR}}-j u k a r u_{\mathrm{PSM}}-\boldsymbol{n g} \boldsymbol{k u}\right]_{\mathrm{PSP}} n g u=y i_{\mathrm{PSR}}=l u_{\mathrm{PSP}} \quad$ tawirrjip

1MIN.DAT-ERG child-ERG CAT=1MIN.O=3AUG.S pelt

pa-ni marluka-wu kurrurij.

hit-PST old.man-DAT car

'The children of mine threw rocks at the old man's car.' (VW: FM13_a194: 1:36min)

In (18) the possessor is embedded in a benefactive construction which is also an oblique argument, thus both the possessor and the benefactive NP are crossreferenced as obliques. Benefactive constructions are discussed in more detail in Section 5.

(18) Gurindji

Kajirri-lu $\quad n g u=y i_{\mathrm{PSR}}=\boldsymbol{r l a} \boldsymbol{B}_{\mathrm{BEN}} \quad$ kampa-wu $\left[\right.$ ngayiny $\mathrm{PSR}_{\mathrm{PS}}-\boldsymbol{k} \boldsymbol{u}$

woman-ERG CAT=1MIN.O=3.OBL cook-POT 1MIN.DAT-DAT

$\left.\boldsymbol{k a r u}_{\mathrm{PSM}}-\mathbf{w u}\right]_{\mathrm{BEN}}$ ngarin.

child-DAT meat

'The old woman will cook the meat for the child of mine.' (VW: FM13_a194:

2.33min)

Since the object/oblique bound pronoun series in most Ngumpin-Yapa languages (other than Walmajarri) cross-references both objects and obliques, it is not immediately obvious that in these languages the possessor in possessor dissension constructions is functioning as an oblique rather than an object. However, if the possessor in the possessor dissension construction were a type of object, it would trigger the use of the reflexive pronoun clitic in clauses where 
it is coreferential with the subject (Meakins \& Nordlinger 2014: 235). This is the case in inalienable possession constructions, as shown in (19a), but not for possessor dissension, as shown in (19b), thus providing evidence for its analysis as an oblique even in languages where this is not distinguished by the pronominal clitics.

(19) Bilinarra

a. Nyawa=ma=rna=nyunu ba-ni ngarlaga-la=ma ngayi=rni this $=$ TOP $=1$ MIN.S $=$ RR hit-PST head-LOC $=$ TOP $1 \mathrm{MIN}=\mathrm{ONLY}$ wardan-jawung.

hand-PROP

'I hit myself on the head with my own hand.' (Meakins \& Nordlinger 2014: 235)

b. $\underline{\text { An }}$ gula $=r n a=y \mathbf{n g a y i n y}=m a \quad$ ngamayi $=m a$

and $\mathrm{NEG}=1 \mathrm{MIN} . \mathrm{S}=1 \mathrm{MIN}$.O $1 \mathrm{MIN} . \mathrm{DAT}=\mathrm{TOP}$ mother=TOP ngarrga ma-ni.

remember do-PST

'And I didn't recognise the mother of mine.' (Meakins \& Nordlinger 2014: 96)

Thus inalienable possession and possessor dissension share the structural characteristic of cross-referencing the possessor with a bound pronoun, which differentiates them from alienable possession. In both constructions, the form of the bound pronoun indicates the grammatical role borne by the possessor. However, whereas the possessor in inalienable constructions can perform different grammatical functions (subject, object, etc.), since it is treated as the true verbal argument, the possessor in possessor dissension constructions is always an oblique argument. In this respect, possessor dissension constructions resemble benefactive constructions, as will be discussed in Section 5 .

\subsection{Distinguishing alienable possession}

While inalienable constructions mark an intrinsic relationship between two entities, distance and free association is represented in alienable structures. (Regular) alienable possession in Ngumpin-Yapa languages is expressed by a phrase consisting of (i) a head nominal which encodes the possessum ${ }_{\mathrm{PSM}}$, (ii) a dative-marked dependent nominal/pronominal which encodes the possessor ${ }_{\mathrm{PSR}}$, and (iii) a pronominal clitic cross-referencing the whole possessive $\mathrm{NP}_{\mathrm{PSP}}$ as an argument of the verb, e.g., a subject (20a), object (20b), or indirect object (20c). 
(20) a. Gurindji

Wankawankaj ngu=lu $\boldsymbol{u}_{\mathrm{PSP}} \quad$ [nyawa $=\boldsymbol{m a}$ yarrularn $=\boldsymbol{m a}$

bad.REDUP CAT=3AUG.S this=TOP young=TOP

ngantipany $\left._{\mathrm{PSR}}\right]_{\mathrm{PSP}}$.

1AUG.EXC.DAT

'Our young people are no good.' (McConvell 1996: 114-15)

b. Bilinarra

Baya-rni=wuliny $_{\mathrm{PSP}}\left[\text { ngayiny }_{\mathrm{PSR}} \text { warlagu jiya }\right]_{\mathrm{PSP}}$.

bite-PST=3UA.O 1MIN.DAT dog kangaroo

'He killed my dog and kangaroo.' (Meakins \& Nordlinger 2014: 203)

c. Bilinarra

Bala $=r n a=r l a_{\mathrm{PSP}} \quad$ warlag bu-nggu [yabagaru-wu

CONS=1MIN.S=3.OBL search pierce-POT little-DAT

ngayiny $\left._{\mathrm{PSR}}-\mathrm{gu}\right]_{\mathrm{PSP}}$.

1MIN.DAT-DAT

'So I can look around for my little (boy) who left a long time ago.' (Meakins \& Nordlinger 2014: 204)

Thus, in these constructions it is the possessum, rather than the possessor, which is cross-referenced with the pronominal clitic.

Like alienable possession, in the possessor dissension construction the possessor is a modifier within the larger possessive NP and is marked with the dative case when overt. As a modifier, the possessor NP in each of these constructions must also carry additional case marking in agreement with the relational case of the head nominal which it modifies. The difference between the two constructions is that in alienable possession constructions, as in (21a), it is only the whole possessive NP that is cross-referenced with a bound pronominal clitic, whereas in possessor dissension, as in (21b), the possessor is also cross-referenced, resulting in the double-marking discussed above. Furthermore, in the alienable possession construction the possessor NP is obligatory, whereas in the possessor dissension construction, the possessor NP can be omitted as the possessor is cross-referenced with a bound pronoun.

(21) a. Bilinarra

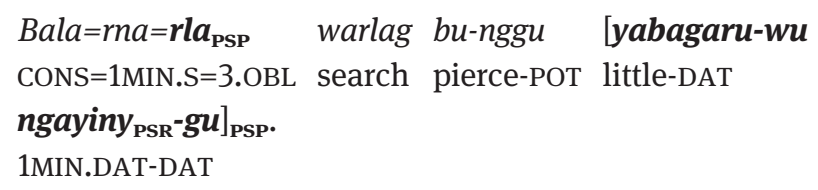

'So I can look around for my little (boy) who left a long time ago.' (Meakins \& Nordlinger 2014: 204) 
b. Gurindji

$\left[\text { Ngayiny }_{\mathbf{P S R}}-\mathbf{j u} \text { karu-ngku }\right]_{\mathbf{P S P}} n g u=\mathbf{y i}_{\mathbf{P S R}}=\boldsymbol{l u}_{\mathbf{P S P}}=r l a_{\mathbf{B E N}} \quad k a-n y a$
1MIN.DAT-ERG child-ERG CAT=1MIN.O=3AUG.S=3.OBL take-PST
ngarin marluka-wu
meat old.man-DAT
'The children of mine took meat for the old man.' (VW: FM13_a194:
19:48min)

Possessor dissension constructions appear to be the preferred way of encoding alienable possession for human possessors. Moreover human possessors appear to be the only type of possessor possible in these constructions, as attempts to elicit animal and inanimate possessor types in this construction were rejected by Gurindji speakers. Thus the use of cross-referencing bound pronouns for the human possessors in these constructions may reflect a common crosslinguistic tendency for referents with high cognitive accessibility (such as human referents) to receive less formal encoding (such as dependent agreement marking, rather than overt NPs) (Siewierska 2011).

Beyond possessor animacy, however, functional differences between possessor dissension constructions and regular alienable possession are not apparent from our Bilinarra and Gurindji data, and unfortunately it is also not a contrast that speakers of the languages have clear intuitions about. Furthermore, such semantic differences are also not discussed in any of the other descriptions of Ngumpin-Yapa languages since the possessor dissension construction is not even identified in these sources. Thus in our current corpus it is not possible to determine any semantic differences between these two constructions, but we assume a detailed discourse study (should extensive discourse materials be available) could reveal interesting differences. ${ }^{16}$

Other languages which present similar choices in encoding alienable possessors show differences relating to information structure. For example, in her brief typological survey of the phenomenon Nikolaeva (2014) refers to this type of construction as involving "internal prominent possessors". ${ }^{17}$ Similarly Kibrik \& Seleznev (1982),

16 A reviewer suggests that one analysis of the possessor in the dissension constructions might be as being implicated in some way in the event, i.e., it is represented as being indirectly involved in the event through being cross-referenced by a pronominal clitic. This analysis is certainly one possibility, but we are unable to establish such facts from our current corpus.

17 In more recent unpublished work, Nikolaeva uses the term "prominent internal possessor" or PiP. We have avoided this term because it is not yet clear to us whether this construction in the Ngumpin-Yapa languages we discuss relates to prominence. 
cited in Dalrymple \& Nikolaeva (2011: 120 et passim), claim that the referent of nonsubject agreement in Tabassaran (North Caucasian) is more prominent than nonagreeing referents, which means that the possessor in a sentence such as (22) becomes prominent when -as '1SG.GEN' is used instead of - $u v$ ' 3 '.

(22) Tabassaran

Jas agaji dumu uvcun-uv / uvcun-as

I.GEN father.ERG he.NOM beat-3 beat-1SG.GEN

'My father has beaten him.' (Dalrymple \& Nikolaeva 2011: 121)

And in Itelmen (Chukotko-Kamchatkan, Russia), the use of an oblique bound pronoun in intransitive sentences to cross-reference a possessor of a subject, in contrast to a subject bound pronoun cross-referencing the whole possessive phrase, is likewise claimed to accord prominence to a possessor (Bobaljik \& Wurmbrand 2002: 24 onwards).

It is possible that prominence of the possessor plays a role in the possessor dissension constructions that we describe in this article. However, a more detailed discourse-based study is needed to establish the complete semantic and information-structural effects of the possessor dissension construction over the regular alienable possession construction, and we leave this for future research.

\section{Contrast with benefactive/malefactive constructions}

The use of the object/oblique bound pronoun in possessor dissension constructions to cross-reference the possessor as an oblique argument makes them look on the surface like benefactive/malefactive or goal constructions. ${ }^{18}$ These construction types also involve the use of an object/oblique pronominal clitic to cross-reference a human (or at least animate) participant, which

18 Simpson (1991) also notes ambiguities between possessor dissension (although she does not use this term) and causal constructions by giving alternate translations of sentences containing these constructions, e.g., 'The horse might tread on my child while it's sleeping' or 'The horse is liable to tread on the child while it's sleeping because of me' (Simpson 1991: 389, see also her example (344) which is repeated in this article as (16c)). 
is dative-marked if expressed by an overt nominal or free pronoun. The following examples illustrate this with a beneficiary (23a), goal (23b), and maleficiary (23c).

(23) Bilinarra

a. Wanyja-rru warrgab wajarra, gardiba-wu=rlaangulu leave-POT dance corroborree whitefellas-DAT=1AUG.INC $>3$ AUG.O jala $=m a$. now $=$ TOP

'We'll dance a corroboree for the whitefellas today.' (Meakins \& Nordlinger 2014: 131)

b. Nyawa=ma=rna=nyjurra ya-na-rni nyurruluny murla-nggurra this=TOP=1MIN.S=2AUG.O go-PRS-HITH 2AUG.DAT this-ALL jarragab-gu. talk-DAT 'I came here to you mob to talk.' (Meakins \& Nordlinger 2014: 132)

c. Jangala-lu garrwa-ni=ma=yi.

SUBSECT-ERG hold-PST=TOP=1MIN.O

'Jangala married me.'

Jarrarda $=\mathbf{y i}$ ma-ni.

love.magic=1MIN.O do-PST

'(Because) he did love magic on me.'19 (Meakins \& Nordlinger 2014: 449)

As a result of this similarity in surface structure, many sentences are ambiguous (outside of context) as to whether they should be interpreted as a possessor dissension construction or benefactive/malefactive construction. ${ }^{20}$ For example, (24a) could be understood as 'The sun will dry out the pieces of bark of mine' (possessor dissension) or 'The sun will dry the pieces of bark out for me' (benefactive). Similarly (24b) could be interpreted as either 'This blunt axe of mine is making it hard to cut (the wood)' (possessor dissension) or 'This blunt axe is making it hard for me to cut (the wood)' (malefactive).

19 This construction is syntactically identical to the benefactive; however, given that the speaker did not want to marry Jangala, it is interpreted as a malefactive.

20 Of course, this ambiguity only arises in examples which do not exhibit case agreement as discussed in Section 3 above, which establishes the possessor and possessive nominals to belong to a single syntactic constituent. We return to this issue below. 
(24) Gurindji

a. Nyila-rra=ma, parnngirri=ma wartartart jiya-rna-na that-PL=TOP bark=TOP dry.REDUP burn-IMPF-PRS ngu=yi. CAT $=1 \mathrm{MIN} . \mathrm{O}$

'The sun will dry the pieces of bark out for me.' or 'The sun will dry out the pieces of bark of mine.' (Meakins 2014: 293)

b. Ngu=yi maral pa-na-na tuja-ngku murlu-ngku.

CAT=1MIN.O cut.badly hit-IMPF-PRS blunt-ERG this-ERG

'This blunt axe is making hard for me to cut (the wood).' or 'This blunt axe of mine is making it hard to cut (the wood).' (VW: FM07_a05_1a: 7:01min)

Nonetheless in some examples a benefactive/malefactive interpretation is not appropriate showing clearly that the possessive meaning is intended. In (25) the bound pronoun =ngandiba is semantically incompatible with the benefactive reading 'for us'.

(25) Bilinarra

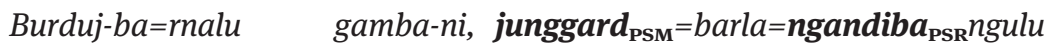
set.alight=1AUG.EXC.S cook-PST smoke=FOC=3AUG.S $>1$ AUG.EXC.O nya-nya.

intake-PST

'We lit (a fire) and they saw the smoke of ours.' (Meakins \& Nordlinger 2014: 313)

Furthermore, benefactive/malefactive constructions can be distinguished from possessor dissension constructions by case agreement marking: in benefactive/ malefactive constructions the dative-marked NP has its own clausal relation and therefore never shows case agreement with another NP in the clause. In possessor dissension constructions however, as discussed in Section 3, the possessor shows case agreement with the possessum, as shown in (26) (repeated from above).

(26) Gurindji

$\left[\text { Ngayiny }_{\mathrm{PSR}}-\mathbf{j u} \quad \boldsymbol{k} \text { aru-ngku }\right]_{\mathrm{PSP}} \quad n g u=y \boldsymbol{i}_{\mathrm{PSR}}=\boldsymbol{l u}_{\mathrm{PSP}}=r l a_{\mathrm{BEN}} \quad k a-n y a$ 1MIN.DAT-ERG child-ERG AUX=1MIN.O=3AUG.S=3.OBL take-PST

ngarin marluka-wu $\mathbf{B E N}_{\mathbf{B N}}$.

meat old.man-DAT

'The children of mine took meat for the old man.' (VW: FM13_a194: 19:48min) 
Finally, the two constructions can be shown to be distinct by the fact that they may co-occur. In (27a) the possessive phrase ${ }_{\mathrm{PSP}}$ 'the child of mine' is embedded within a benefactive construction ${ }_{\mathrm{BEN}}$ 'for the child of mine'. In this sentence, the pronominal clitic $=y i$ 'of mine' cross-references the possessor in the possessor dissension construction and =rla 'for ...' cross-references the entire benefactive construction (which is a discontinuous NP). This sentence contrasts with (27b) which is an example of an alienable possessive phrase embedded in an inalienable possessive phrase within a benefactive construction. The crucial difference is the lack of pronominal clitic in (27b) to refer to the 1st person possessor.

(27) Gurindji

a. $[\text { Karu-wu }]_{\mathrm{BEN}} n g u=y i_{\mathrm{PSR}}=\boldsymbol{r l a} \boldsymbol{a}_{\mathrm{BEN}} \quad\left[\text { ngayiny }_{\mathrm{PSR}}-\boldsymbol{k u}\right]_{\mathrm{BEN}}$ jiya-wu. child-DAT CAT=1MIN.O=3.OBL 1MIN.DAT-DAT boil-POT 'It will boil for the child of mine.' (VW: FM07_a01_1e: 2:02min)

b. $N g u=r n a=r l a_{\mathrm{PSR} 2} \quad k a m p a-w u \quad\left[\boldsymbol{k a r u}_{\mathrm{PSM1}}-\boldsymbol{w u}\right.$ ngayiny-ku $\boldsymbol{P S R}_{\mathrm{PSR2}}$ CAT=1MIN.S=3.OBL cook-pot child-DAT 1MIN.DAT-DAT

\section{ngarlaka-wu PSM2}

head-DAT

'I’m cooking it for my child's head.' (VW: FM07_a01_1e: 1:18min)

In (28) we see three bound pronominal clitics, one referring to the "dissenting" possessor within the subject $(=y i)$, another referring to the 3rd person plural subject within which this possessor is contained $(=l u)$, and the third crossreferencing the benefactive NP 'old man' $(=r l a)$.

(28) Gurindji

\begin{tabular}{|c|c|c|}
\hline$\left[\right.$ Ngayiny $_{\mathrm{PSR}}-j u$ & karu-ngku $]_{\mathrm{PSP}}$ & $n g u=\boldsymbol{y} \boldsymbol{i}_{\mathbf{P S R}}=\boldsymbol{l u}_{\mathrm{PSP}}=\boldsymbol{r l a} \boldsymbol{a}_{\mathrm{BEN}} \quad k a-n y a$ \\
\hline 1MIN.DAT-DAT & child-ERG & $\mathrm{CAT}=1 \mathrm{MIN} . \mathrm{O}=3 \mathrm{AUG} . \mathrm{S}=3 . \mathrm{OBL}$ take-PST \\
\hline
\end{tabular}

'The children of mine took meat for the old man.' (VW: FM13_a194: 1: 59min)

The particularly complex example in (29) demonstrates the limits of the clitic cluster in Gurindji. In this example, two possessor dissension constructions are found, one within a transitive subject and one within the benefactive adjunct. As a result an additional 3rd person oblique suffix =nyanta is used. ${ }^{21}$

21 Note that this sentence was given in an elicitation session. A sequence of four clitics is also only observed in the Warlpiri corpus through elicitation (Nash 1996). In other clauses, =nyanta usually refers to an unexpressed and perhaps deliberately vague purpose 'for some reason or other'. 
(29) Gurindji

$\left[\text { Ngayiny-ju } u_{\mathrm{PSR} 1} \quad k \text { aru-ngku }\right]_{\mathrm{PSP}} \quad n g u=y i_{\mathrm{PSR} 1}=\operatorname{lu}_{\mathrm{PSP}}=r l a_{\mathrm{PSR} 2}=$ nyanta $\boldsymbol{B}_{\mathrm{BEN}}$ 1MIN.DAT-ERG child-ERG CAT=1MIN.O=3AUG.S=3.OBL=3.0BL

ka-nya ngarin [nyanuny-k $u_{\mathrm{PSR2}}$ ngumparna-wu $]_{\mathrm{BEN}}$. bring-PST meat 3MIN.DAT-DAT husband-DAT

'The children of mine take the meat for her husband.' (VW: FM13_a195: 4:38min)

Polysemy between benefactives (and malefactives) and possessive constructions is well known crosslinguistically (e.g., Lichtenberk 2002; Rapold 2010; Zúñiga \& Kittilä (eds.) 2010), and is common in Australian languages (e.g., common functions of dative case) (Blake 1977; Dixon 2002: 394-401). However, while it seems likely that the existence of the benefactive construction in the Ngumpin-Yapa languages may have enabled the development of the possessor dissension construction, the two constructions are now clearly distinct. Examples such as (28) and (29) containing both a possessor dissension construction and a benefactive construction demonstrate clearly that the former is a distinct construction from the benefactive/malefactive construction, as well as being different to the alienable and inalienable possession constructions as shown in Section 4.

\section{Theoretical and typological context}

In the possessor dissension construction in Ngumpin-Yapa languages (e.g., (28)) we find an internal NP modifier (the possessor NP) that is both embedded within an argument NP, and agreed with at the clausal level as if it were a clausal argument. Such behaviour challenges assumptions about how agreement generally works, as has been observed by researchers discussing this phenomenon in languages such as Maithili (Stump \& Yadav 1988; Yadav 1996; Bickel et al. 1999) and Tundra Nenets (Nikolaeva 2014). In short, while it is standard for arguments (and potentially also adjuncts) to be cross-referenced at the clausal level, such agreement is expected to be made with the HEAD of the argument/adjunct NP, and not with a modifier embedded within it (e.g., Corbett 2006). Furthermore, Sierwierska (2011: 337) notes that clausal agreement is overwhelmingly found with subjects crosslinguistically and rarely with obliques (only $6 \%$ of languages surveyed), and agreement with possessors is so rare as to not even feature in her figures.

The fact that the embedded possessor NP and the possessive NP as a whole are both cross-referenced at the clausal level in these Ngumpin-Yapa languages, 
results in a construction where there are two distinct agreement markers crossreferencing (different parts of) the same NP. In (28), for example, both the $=y i$ '1MIN.O' clitic and the =lu '3AUG.S' clitic agree with referents contained within the subject NP: the latter agrees with the head of the NP (the possessum) and the former agrees with the embedded possessor. This possibility has so far not been reported at all in the agreement literature, as far as we are aware.

The possessor NP in possessor dissension constructions shares properties with non-selected datives (Bosse et al. 2012; Camilleri \& Sadler 2012) in that the possessor NP is not selected by the verb, and yet is cross-referenced with clause-level agreement morphology. Bosse et al. (2012) identify four types of non-selected arguments: external possessors, benefactives, attitude holders, and affected experiencers. Of these, the possessor dissension construction is clearly closest to the external possession type (although the Ngumpin-Yapa languages have the benefactive type also, as we saw in Section 5 above). However, in the typology of Bosse et al. (2012) as well as the typological literature on this issue more generally (e.g., Payne \& Barshi (eds.) 1999), the external possession construction is usually restricted to inalienable possession, whereas the Ngumpin-Yapa languages have another (inalienable) construction type for this and instead restrict the possessor dissension construction to alienable possession. Thus, the Ngumpin-Yapa possessor dissension construction does not easily fit within the Bosse et al. (2012) typology, and in fact given that the possessor NP remains clearly embedded as a modifier of the possessive NP, it is not clear that it would qualify as a nonselected dative in Bosse et al. (2012) terms.

Camilleri \& Sadler (2012) discuss non-selected datives in Maltese, including external possession constructions, and provide an analysis within the LexicalFunctional Grammar (LFG) framework for these which consists of a morphosemantic operation in the lexicon which adds an argument (with certain lexical entailments) to a predicate (30a) and introduces a (dative) pronominal affix associated with the additional argument at the clausal level (informally noted in (30a) as " + affected/ben/poss"). The effect of this morphosemantic operation on a predicate is shown in $(30 \mathrm{~b})$, where the argument structure of the verb is augmented to include an additional argument (of either the affected experiencer, benefactive, or external possessor type), which is mapped to the grammatical function of "restricted object" by the principles of LFG's lexical mapping theory (see Camilleri \& Sadler (2012) for discussion). ${ }^{22}$

22 Camilleri \& Sadler (2012) use the diacritic +OM to indicate that the verbal morphology includes an object affix. 
(30) a.

a.
+ DAT.OM
$<\arg 3>$

b.

$$
\begin{array}{cccc}
\mathrm{x} & \mathrm{y} & \mathrm{a} \\
\text { V+DAT.OM } & <\text { arg1 } & \arg 2 & \arg 3> \\
\text { SUBJ } & \text { OBJ } & \text { OBJ }_{\text {affected/ben/poss }}
\end{array}
$$

Camilleri \& Sadler (2012) show how their approach accounts nicely for the non-selected datives they discuss in Maltese, but unfortunately this approach does not extend easily to the Ngumpin-Yapa languages for the following reasons.

Firstly, as we have seen in Section 3, the possessor in the possessor dissension construction remains clearly a modifier within the argument NP, as shown by its case marking, case agreement, and positional facts. This is not captured by treating it as a non-selected argument of the clausal predicate since on this approach it would be analysed as an independent argument of the verb (as shown in (30b)), which would leave the case agreement facts unaccounted for.

Secondly, as shown in Section 5, the possessor dissension construction can co-occur with the benefactive, and we can also have two possessor dissension constructions in one clause (29), showing that we would need to allow for multiple non-selected datives to be added to a predicate's argument structure; a fact that does not follow naturally from the morphosemantic rule given by Camilleri \& Sadler (2012), which assumes that only one non-selected dative will be added to any verb.

Rather, we have in the Ngumpin-Yapa languages a construction type in which clause-level agreement can operate within NPs as well as at the clausal level: the clause-level bound pronouns can cross-reference clausal arguments/ adjuncts, as well as possessors that are embedded within these, doing both within the one construction. In other words, the possessor dissension construction is an example of verbal agreement with a possessor, without any possessor "raising".

These facts challenge our standard assumptions about clausal structure and agreement phenomena. We have shown that the possessor is clearly embedded syntactically within the possessive NP, as shown most clearly by the fact that it must agree in case with the possessum head (28). Yet the set of agreement clitics that otherwise cross-reference clause-level grammatical functions such as subject and object are also used to agree with this embedded possessor. Thus, this construction suggests that we need to revise our standard assumptions about agreement to allow clause-level agreement markers to 
be controlled by both NP arguments/adjuncts and the possessor NPs embedded within them. ${ }^{23}$

\section{Conclusion}

This article has presented evidence for the existence of a distinct possessor dissension construction in Ngumpin-Yapa languages, which can be distinguished on structural and semantic grounds from other possessive constructions and the benefactive. This construction is used as an alternative to alienable possessives marking the possessor with both a cross-referencing pronominal clitic and a dative case suffix. The features of the three possessive constructions and the benefactive are summarised in Table 2.

Table 2: Summary of features of constructions.

\begin{tabular}{|c|c|c|c|c|}
\hline Construction & $\begin{array}{l}\text { Case on } \\
\text { possessor }\end{array}$ & $\begin{array}{l}\text { Bound pronoun } \\
\text { cross-references }\end{array}$ & $\begin{array}{l}\text { Grammatical function } \\
\text { of bound pronoun }\end{array}$ & $\begin{array}{l}\text { Function of } \\
\text { construction }\end{array}$ \\
\hline $\begin{array}{l}\text { Inalienable } \\
\text { possession }\end{array}$ & core & $\begin{array}{l}\text { possessor only } \\
\text { (argument of verb) }\end{array}$ & $\begin{array}{l}\text { subject, object/ } \\
\text { oblique (depending } \\
\text { on grammatical } \\
\text { relation of possessor) }\end{array}$ & $\begin{array}{l}\text { possessum is a body } \\
\text { part, shadow, image }\end{array}$ \\
\hline $\begin{array}{l}\text { Alienable } \\
\text { possession }\end{array}$ & dative & $\begin{array}{l}\text { whole possessive } \\
\text { phrase (argument } \\
\text { of verb) }\end{array}$ & $\begin{array}{l}\text { subject, object/ } \\
\text { oblique (depending } \\
\text { on grammatical } \\
\text { relation of possessive } \\
\text { phrase) }\end{array}$ & $\begin{array}{l}\text { possessum is all other } \\
\text { potentially possessed } \\
\text { objects }\end{array}$ \\
\hline $\begin{array}{l}\text { Possessor } \\
\text { dissension }\end{array}$ & dative & $\begin{array}{l}\text { possessor } \\
\text { (oblique) and } \\
\text { whole possessive } \\
\text { phrase }\end{array}$ & $\begin{array}{l}\text { POSSESSOR: oblique } \\
\text { only POSSESSIVE } \\
\text { PHRASE: subject, } \\
\text { object/oblique } \\
\text { (depending on } \\
\text { grammatical function) }\end{array}$ & $\begin{array}{l}\text { preferred construction } \\
\text { for human possessors } \\
\text { of alienable } \\
\text { possessums }\end{array}$ \\
\hline $\begin{array}{l}\text { Benefactive/ } \\
\text { malefactive }\end{array}$ & dative & $\begin{array}{l}\text { beneficiary/ } \\
\text { maleficiary } \\
\text { (adjunct) }\end{array}$ & $\begin{array}{l}\text { oblique only (always } \\
\text { an adjunct) }\end{array}$ & $\begin{array}{l}\text { introduces a } \\
\text { beneficiary/ } \\
\text { maleficiary of an event }\end{array}$ \\
\hline
\end{tabular}

23 In some languages with this construction type, as reported by Nikolaeva (2014), the situation is made more intriguing by the fact that the embedded possessor NP is also visible for other syntactic processes such as switch-reference. We have so far found no evidence for this in the Ngumpin-Yapa languages. 
Possessor dissension constructions have not been discussed in these terms elsewhere in the descriptive literature on possession in Australian languages (Blake 1977; Chappell \& McGregor (eds.) 1995; Dixon 2002: 394-401). Nor have they been previously identified for Ngumpin-Yapa languages, despite examples being present in many existing sources such as those provided above. In fact, examples can also be found in other Australian languages outside the NgumpinYapa family such as Bardi (31a), Gangalidda (also called Yukulta) (31b), ${ }^{24}$ and Bininj Gun-Wok (31c) in which it arises as a special use of the benefactive applicative construction (see Evans (2003: 428-429) for discussion):

a. Bardi

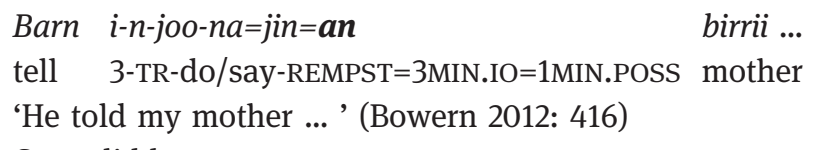

b. Gangalidda

Dan-ma=ba yakurli ngumban-inja dirrgul-inja.

this-STAT(ABS)=2SG.OBL fish(ABS) your-DAT husband-DAT

'That fish is for your husband.' (Keen 1983: 228)

c. Bininj Gun-Wok

Duruk ngarduk ngan-marne-bo-m.

dog my 3/1-BEN-kill-PP

'Someone shot my dog.' (Evans 2003: 428)

As discussed in Section 6, this construction type challenges the standard assumptions about the locality of agreement. In this construction we see a morphosyntactic mismatch: argument agreement morphology treats the possessor $\mathrm{NP}$ as if it were visible at the clausal level, while positional and case marking facts show it to be syntactically embedded within the possessum NP. Furthermore, in this construction we find clause-level agreement marking used to refer to different parts of the same argument NP at once, one cross-referencing the whole argument $\mathrm{NP}$, and the other cross-referencing the possessor embedded within it - a phenomenon that has not been previously reported in the typological literature on agreement, as far as we are aware. The possessor dissension construction in Ngumpin-Yapa languages, therefore, requires us to revisit our understanding of clausal agreement processes and the relationship between the clause and the NPs embedded within it, and has significant implications for typologies of agreement and theories of syntactic structure.

24 Our thanks to Erich Round for pointing us to this construction in Gangalidda. For further examples, see Round (2014: 32). 
Acknowledgements: The collection of the Bilinarra data was funded by the University of Melbourne in 1990, Diwurruwurru-jaru Aboriginal Corporation (2000-2007), an AIATSIS grant “Bilinarra Dreaming Lines” (2003-2004), and the Jaminjungan and Eastern Ngumpin DoBeS project (2008-2009). The collection of Gurindji data was funded by the Jaminjungan and Eastern Ngumpin DoBeS project (2008-2009) and a Hans Rausing Endangered Languages ELDP project (2009-2011). Earlier versions of this article were presented at the Australian Languages Workshop in Queensland in March 2013 and the Association for Linguistic Typology conference in Leipzig in August 2013. We thank the audiences of these presentations for many helpful questions and comments, and especially Mary Laughren, David Nash, Irina Nikolaeva, Jane Simpson, Tasaku Tsunoda, and all of those who responded to our post "Verbal agreement with internal NPmodifiers" on the Lingtyp list in August 2014 (see http://listserv.linguistlist.org/ pipermail/lingtyp/). We are also very grateful to Frans Plank, Sandy Ritchie, and three anonymous reviewers for providing useful feedback on a previous draft, which led to substantial improvements. A number of language consultants were instrumental in the collection of the Bilinarra and Gurindji data. We are grateful to Hector Waitbiari Jangari ${ }^{\dagger}$, Anzac Munganyi Jangari ${ }^{\dagger}$, Ivy Kulngari NangariNambijina $^{\dagger}$ (Bilinarra), Violet Wadrill Nanaku, Topsy Dodd Ngarnjal Nangari, and Biddy Wavehill Yamawurr Nangala (Gurindji).

Abbreviations: $1 / 2 / 3=1 \mathrm{st} / 2 \mathrm{nd} / 3 \mathrm{rd}$ person; $\mathrm{ABL}=$ ablative; $\mathrm{ABS}=$ absolutive; $\mathrm{ACC}=$ accusative; $\mathrm{ALL}=$ allative; $\mathrm{ALONE}=$ alone; $\mathrm{AND}=$ and; $\mathrm{AUG}=$ augmented; $\mathrm{AUX}=\mathrm{aux}$ iliary; $\mathrm{BEN}=$ benefactive; $\mathrm{CAT}=$ catalyst; $\mathrm{CONS}=$ consequence; $\mathrm{DAT}=$ dative; $\mathrm{DU}=$ dual; DUB = doubt; DYAD = kinship pair; EP = epenthetic; ERG = ergative; $E X C=$ exclusive; FACT = factive; FOC = focus; GEN = genitive; $\mathrm{HITH}=$ hither; $\mathrm{IMPF}=$ imperfective; INC = inclusive; $\mathrm{INCHO}=$ inchoative; $\mathrm{IO}=$ indirect object; LOC = locative; $\mathrm{MIN}=$ minimal; NEG = negative; NMLZ = nominaliser; NPST = non-past; $\mathrm{O}=$ object; $\mathrm{OBL}=$ oblique; $\quad$ ONLY = restrictive; $\quad$ OTHER $=$ an/other; $\quad$ PERF $=$ perfect; $\quad \mathrm{PL}=$ plural; $\quad \mathrm{POSS}=$ possessive; $\mathrm{POT}$ = potential; $\mathrm{PP}=$ past perfective; $\mathrm{PROP}=$ proprietive; $\mathrm{PRS}=$ present; $\mathrm{PSM}=$ possessum; $\mathrm{PSP}=$ possessive phrase; $\mathrm{PSR}=$ possessor; $\mathrm{PST}=$ past $;$ REMPST = remote past; $\mathrm{RR}=$ reflexive/reciprocal; $\mathrm{S}$ =subject; $\mathrm{SG}=$ singular; STAT=stative; SUBSECT $=$ subsection term; TOP = topic; $\mathrm{TR}=$ transitive; $\mathrm{UA}=$ unit augmented.

\section{References}

Bickel, Balthasar, Walter Bisang \& Yogendra P. Yadava. 1999. Face vs. empathy: The social foundations of Maithili verb agreement. Linguistics 37. 481-518. 
Blake, Barry J. 1977. Case marking in Australian languages. Canberra: AIAS Press.

Blake, Barry J. 1983. Structure and word order in Kalkatungu: The anatomy of a flat language. Australian Journal of Linguistics 3. 143-175.

Bobaljik, Jonathan David \& Susi Wurmbrand. 2002. Notes on agreement in Itelmen. Linguistic Discovery 1(1). http://doi.org/10.1349/PS1.1537-0852.A.21

Bosse, Solveig, Benjamin Bruening \& Masahiro Yamada. 2012. Affected experiencers. Natural Language \& Linguistic Theory 30. 1185-1230.

Bowern, Claire. 2012. A grammar of Bardi. Berlin: De Gruyter Mouton.

Bresnan, Joan \& Sam A. Mchombo. 1987. Topic, pronoun, and agreement in Chicheŵa. Language 63. 741-782.

Camilleri, Maris \& Louisa Sadler. 2012. On the analysis of non-selected datives in Maltese. In Miriam Butt \& Tracy Holloway King (eds.), Proceedings of LFG12, 118-138. Stanford, CA: CSLI Publications. http://web.stanford.edu/group/cslipublications/cslipublications/LFG/ 17/papers/lfg12camillerisadler.pdf

Cataldi, Lee. 2011. A dictionary of Ngardi. Unpublished manuscript.

Chappell, Hilary \& William McGregor. 1995. Prolegomena to a theory of inalienability. In Chappell \& McGregor (eds.) 1995, 3-30.

Chappell, Hilary \& William McGregor (eds.). 1995. The grammar of inalienability: A typological perspective on body part terms and the part-whole relation. Berlin: Mouton de Gruyter.

Comrie, Bernard. 2003. When agreement gets trigger-happy. Transactions of the Philological Society 101. 313-337.

Corbett, Greville G. 2003. Agreement: Terms and boundaries. In William Earl Griffin (ed.), The role of agreement in natural language: Proceedings of the Fifth Annual Texas Linguistics Society Conference, 109-121. Austin, TX: Texas Linguistics Society. http://tls.ling.utexas.edu/2001tls/Corbett.pdf

Corbett, Greville G. 2006. Agreement. Cambridge: Cambridge University Press.

Dalrymple, Mary \& Irina Nikolaeva. 2011. Objects and information structure. Cambridge: Cambridge University Press.

Dench, Alan \& Nicholas Evans. 1988. Multiple case-marking in Australian languages. Australian Journal of Linguistics 8. 1-48.

Dixon, R. M. W. 1980. The languages of Australia. Cambridge: Cambridge University Press.

Dixon, R. M. W. 2002. Australian languages: Their nature and development. Cambridge: Cambridge University Press.

Evans, Nicholas. 2003. Bininj Gun-wok: A pan-dialectal grammar of Mayali, Kunwinjku and Kune (Pacific Linguistics 541). Canberra: Australian National University.

Goddard, Cliff. 1982. Case systems and case marking in Australian languages: A new interpretation. Australian Journal of Linguistics 2. 167-196.

Hale, Kenneth. 1982. Some essential features of Warlpiri verbal clauses. In Stephen M. Swartz (ed.), Papers in Warlpiri grammar: In memory of Lothar Jagst (Work Papers of SIL-AAB A-6), 217-315. Darwin, N.T.: Summer Institute of Linguistics.

Hale, Kenneth. 1983. Warlpiri and the grammar of non-configurational languages. Natural Language \& Linguistic Theory 1. 5-47.

Heath, Jeffrey. 1986. Syntactic and lexical aspects of nonconfigurationality in Nunggubuyu (Australia). Natural Language \& Linguistic Theory 4. 375-408.

Hudson, Joyce. 1978. The core of Walmatjari grammar. Canberra: Australian Institute of Aboriginal Studies. 
Ise, Magumi. 1998. Grammatical sketch of Malngin language. Sapporo: University of Hokkaido MA thesis.

Keen, Sandra. 1983. Yukulta. In R. M. W. Dixon \& Barry Blake (eds.), Handbook of Australian languages, Vol. 3, 191-304. Amsterdam: Benjamins.

Kibrik, Aleksandr E. \& Mixail G. Seleznev. 1980. Sintaksis i morfologija glagol'nogo soglasovanija $v$ tabasaranskom jazyke. [The syntax and morphology of verbal agreement in Tabassaran.] In Tabasaranskie ètjudy: Materialy dagestanskoj èkspedicii 1979, 17-33. Moskva: Izdatel'stvo Moskovskogo universiteta.

Laughren, Mary \& Robert Hoogenraad. 1996. A learner's guide to Warlpiri: Tape course for beginners, based on a tape course prepared by Professor Kenneth Hale and Robin Japanangka Granites. Alice Springs, N.T.: IAD Press.

Lichtenberk, Frank. 2002. The possessive-benefactive connection. Oceanic Linguistics 41. 439-474.

McConvell, Patrick. 1996. Gurindji grammar. Unpublished manuscript.

McConvell, Patrick. 2009. Loanwords in Gurindji, a Pama-Nyungan language of Australia. In Martin Haspelmath \& Uri Tadmor (eds.), Loanwords in the world's languages: A comparative handbook, 790-822. Berlin: Mouton de Gruyter.

McConvell, Patrick \& Mary Laughren. 2004. Ngumpin-Yapa languages. In Harold Koch \& Claire Bowern (eds.), Australian languages: Reconstruction and subgrouping, 151-177. Amsterdam: Benjamins.

Meakins, Felicity. 2011. Case marking in contact: The development and function of case morphology in Gurindji Kriol. Amsterdam: Benjamins.

Meakins, Felicity. 2014. Nominals as adjuncts or arguments: Further evidence from language mixing. In Rob Pensalfini, Myfany Turpin \& Diana Guillemin (eds.), Language description informed by theory, 283-315. Amsterdam: Benjamins.

Meakins, Felicity. 2015. Not obligatory: Bound pronoun variation in Gurindji and Bilinarra. AsiaPacific Language Variation 1. 128-161.

Meakins, Felicity, Patrick McConvell, Erika Charola, Norm McNair, Helen McNair \& Lauren Campbell. 2013. Gurindji to English dictionary. Batchelor, N.T.: Batchelor Press.

Meakins, Felicity \& Rachel Nordlinger. 2014. A grammar of Bilinarra: An Australian Aboriginal language of the Northern Territory. Berlin: De Gruyter Mouton.

Nash, David. 1986. Topics in Warlpiri grammar. New York: Garland.

Nash, David. 1996. Pronominal clitic variation in the Yapa languages. In William McGregor (ed.), Studies in Kimberley languages in honour of Howard Coate, 117-138. München: Lincom Europa.

Neukom, Lukas. 2001. Santali. München: Lincom Europa.

Nikolaeva, Irina. 2014. Internal prominent possessors. Paper presented at the 6th International Conference on the Syntax of the World's Languages, Pavia, 8-10 September 2014.

Nordlinger, Rachel. 2014. Constituency and grammatical relations in Australian languages. In Harold Koch \& Rachel Nordlinger (eds.), The languages and linguistics of Australia: A comprehensive guide, 215-261. Berlin: De Gruyter Mouton.

O'Shannessy, Carmel. 2009. Language variation and change in a North Australian indigenous community. In James N. Stanford \& Dennis Preston (eds.), Variation in indigenous minority languages, 419-439. Amsterdam: Benjamins.

Payne, Doris \& Immanuel Barshi (eds.). 1999. External possession. Amsterdam: Benjamins.

Rapold, Christian. 2010. Beneficiary and other roles of the dative in Tashelhiyt. In Zúñiga \& Kittilä (eds.) 2010, 351-376. 
Richards, Eirlys. 1979. The Walmatjari noun phrase. In Christine A. Kilham (ed.), Four grammatical sketches: From phrase to paragraph (Work Papers of SIL-AAB A-3), 93-125. Darwin, N.T.: Summer Institute of Linguistics.

Round, Erich. 2014. A short description of Gangalidda (Ganggalida/Yukulta). Unpublished manuscript. Available at https://www.researchgate.net/publication/272509720

Senge, Chikako. 2015. A grammar of Wanyjirra. Canberra: Australian National University doctoral dissertation.

Siewierska, Anna. 2011. Person marking. In Jae Jung Song (ed.), The Oxford handbook of linguistic typology, 322-345. Oxford: Oxford University Press.

Simpson, Jane. 1991. Warlpiri morpho-syntax: A lexicalist approach. Dordrecht: Kluwer.

Stump, Gregory \& Ramawatar Yadav. 1988. Maithili verb agreement and the Control Agreement Principle (Linguistics Faculty Publications, Paper 37). http://uknowledge.uky.edu/lin_fac $\mathrm{pub} / 37$

Tsunoda, Tasaku. 1981. The Djaru language of Kimberley, Western Australia (Pacific Linguistics B-78). Canberra: Australian National University.

Tsunoda, Tasaku. 2001. Wanyjirra texts: 76/13-2, NP(1), NP(2). In Tasaku Tsunoda (ed.), Basic materials in minority languages 2001 (Endangered Languages of the Pacific Rim B-1), 115-204. Kyōto: Nakanishi.

Tsunoda, Tasaku. 2002. Wanyjirra texts: 76/14-1, TM(1), TM(2). In Tasaku Tsunoda (ed.), Basic materials in minority languages 2002 (Endangered Languages of the Pacific Rim B-3), 133-188. Kyōto: Nakanishi.

Yadav, Ramawatar. 1996. A reference grammar of Maithili. Berlin: Mouton de Gruyter.

Zúñiga, Fernando \& Seppo Kittilä (eds.). 2010. Benefactives and malefactives: Typological perspectives and case studies. Amsterdam: Benjamins. 